\title{
Analisis Investasi dan Sensitivitas Unit Usaha Pembiayaan Syariah menuju Spin Off (Studi Kasus: Adira Finance)
}

\section{Investment and Sensitivity Analysis of Sharia Financing Business Unit toward Spin Off (Case Study: Adira Finance)}

\author{
Lita Wulandari ${ }^{1}$, Hermanto Siregar ${ }^{2}$, Hendri Tanjung ${ }^{3}$
}

\author{
${ }^{1}$ Sekolah Bisnis Institut Pertanian Bogor 16151, email: wulandari_lita@yahoo.com \\ ${ }^{2}$ Sekolah Bisnis Institut Pertanian Bogor 16151, email: hermansiregar@yahoo.com \\ ${ }^{3}$ Sekolah Bisnis Institut Pertanian Bogor 16151, email: hendri.tanjung@gmail.com
}

\begin{abstract}
The purpose of this study to determine the level of investment feasibility and sensitivity level of sharia financing business unit in the process towards spin off. The investment feasibility analysis is carried out in two schemes: the funding scheme is fully borne by the sharia unit of Adira Finance and the joint financing scheme of funding of units to be financed. Sensitivity analysis is calculated by the scenario of decreasing the number of units financed and the scenario of increasing the financing composition of joint financing. Parameters to be measured in these two analyzes are: Net Present Value (NPV), Benefit Cost Ratio (B/C ratio), Internal Rate of Return (IRR) and Break Even Point $(B E P)$. Based on the calculation of investment analysis, the sharia business unit is not eligible to be separated into sharia unit business if all funding is charged to sharia business unit. While the results of sensitivity analysis calculations obtained that motor finance products more vulnerable to changes in scenarios than car finance products.
\end{abstract}

Keywords: spin off, sensitivity analysis, investment feasibility, joint financing

\begin{abstract}
Abstrak. Tujuan penelitian ini untuk mengetahui tingkat kelayakan investasi dan tingkat sensitivitas unit usaha pembiayaan syariah dalam proses menuju spin off. Analisis kelayakan investasi yang dilakukan dalam dua skema yakni skema pendanaan sepenuhnya ditanggung oleh unit usaha syariah Adira Finance dan skema joint financing terhadap pendanaan unit yang akan dibiayai. Analisis sensitivitas dihitung dengan skenario penurunan jumlah unit yang dibiayai dan skenario peningkatan komposisi pendanaan joint financing. Parameter yang akan diukur dalam dua analisa ini adalah: Net Present Value (NPV), Benefit Cost Ratio (B/C ratio), Internal Rate of Return (IRR) dan Break Even Point (BEP). Berdasarkan hasil perhitungan analisis investasi diperoleh unit usaha syariah tidak layak untuk dilakukan pemisahan menjadi bisnis unit syariah jika pendanaan seluruhnya dibebankan kepada unit usaha syariah. Sementara hasil dari perhitungan analisis sensitivitas diperoleh bahwa produk pembiayaan motor lebih rentan terhadap perubahan skenario dibandingkan produk pembiayaan mobil.
\end{abstract}

Kata kunci: spin off, analisis sensitivitas, kelayakan investasi, joint financing

\section{PENDAHULUAN}

Peningkatan jumlah unit pembiayaan syariah di tahun 2012 diiringi dengan mulai diberlakukannya kebijakan yang ditetapkan terkait dengan uang muka pada tahun 2012. Dalam Peraturan Menteri Keuangan RI No 43/PMK.010/2012 tentang Uang Muka Pembiayaan Kendaraan Bermotor pada Perusahaan Pembiayaan menetapkan ketentuan uang muka (Down Payment) minimal 20\% - 25\% dari harga jual. Hal ini cukup mempengaruhi penurunan performa penjualan pembiayaan. Kondisi ini mengharuskan perusahaan pembiayaan menerapkan salah satu strategi baru untuk tetap mempertahankan pangsa pasar yakni dengan mendirikan unit usaha pembiayaan syariah.

Dampak dari pertumbuhan jumlah unit usaha pembiayaan syariah menyebabkan meningkatnya jumlah asset dan piutang yang disalurkan oleh pembiayaan berdasarkan prinsip syariah sejak tahun 2012. Namun jika dibandingkan total aset pembiayaan secara syariah masih lebih kecil dibanding pembiayaan konvensional (5.25\% : 94.75\%), begitu pula dengan jumlah piutang pembiayaan 
secara syariah masih lebih kecil dibanding dengan piutang pembiayaan secara konvensional $(5.57 \%$ : 94.43\%) (OJK, 2016).

Otorisasi Jasa Keuangan (OJK) selaku regulator pada Industri Keuangan Non Bank (IKNB) telah mengeluarkan Roadmap sebagai panduan bagi para pelaku industri dan seluruh stakeholder terkait arah dan pengembangan IKNB Syariah. Penyusunan Roadmap Syariah didasarkan atas kajian atau penelitian yang dilakukan OJK terhadap perkembangan IKNB Syariah. Hasil kajian tersebut telah menghasilkan beberapa isu strategis yang dihadapi oleh setiap sektor industri. Dalam kaitan penyusunan Roadmap IKNB Syariah, isu-isu strategis IKNB Syariah menjadi dasar penyusunan rencana aksi.

Pada industri pembiayaan, kebijakan yang tertuang pada POJK No. 28/POJK.05/2014 menjelaskan bahwa multifinance yang memiliki portofolio syariah sebanyak $50 \%$ dari total bisnis atau lima tahun dari POJK tersebut di sah kan wajib melakukan spin off syariah (pemisahan unit bisnis syariah).

Beeson dan Hyden (2012) dalam Hamid (2015) menjelaskan bahwa banyak perusahaan yang telah melakukan spin off untuk meningkatkan daya saing perusahaan dan menambah nilai kepada pemegang saham dengan fokus kepada bisnis utama. Christo dan Falk (2006) dalam Hamid (2015) menunjukkan bahwa faktor kunci dari spin off adalah fokus kepada industri. Dari kedua penjelasan ini dapat dinyatakan bahwa keputusan spin off yang telah dilakukan oleh beberapa unit syariah perbankan dapat memberikan nilai kepada induk perusahaan dan juga para pemegang saham karena induk perusahaan dapat fokus kepada bisnis utama dan anak perusahaan dapat fokus pada pengembangan.

Petimbangan pemisahan unit bisnis menjadi suatu perusahaan baru tidak lepas dari permasalahan yang sering terjadi yakni kelayakan dalam investasi dan pemicu keberlangsungan perusahaan baru tersebut. Analisis kelayakan investasi dan analisis sensitivitas selalu dilakukan untuk mengetahui akibat dari perubahan parameter-parameter produksi terhadap perubahan kinerja sistem produksi dalam menghasilkan keuntungan. Menurut Gittinger (1986) dalam teknik analisis sensitivitas harus diperhatikan oleh analisis yang menilai kelayakan suatu bisnis akibat perubahan-perubahan yang mempengaruhi kelayakan bisnis tersebut. Dalam analisis sensitivitas, setiap kemungkinan harus dicoba yang berarti setiap kali harus dilakukan analisis kembali. Hal ini perlu karena analisis proyek biasanya didasarkan pada proyek-proyek yang mengandung banyak ketidakpastian dan perubahan yang akan terjadi di masa mendatang.

Evaluasi pemisahan unit bisnis dilakukan dengan cara menganalisis usaha dengan berbagai asumsi jika dilakukan spin off. Analisis pemisahan unit bisnis ini merupakan suatu gambaran umum unit usaha pembiayaan syariah apakah akan memberikan benefit, baik untuk keberlanjutan maupun pengembangan bisnis. Analisis yang digunakan untuk mengevaluasi unit usaha pembiayaan syariah ini adalah dengan menggunakan analisis kelayakan investasi dan analisis sensitivitas.

Adira Finance sebagai salah satu perusahaan pembiayaan terbesar di Indonesia telah memiliki Unit Usaha Syariah (UUS) yang berdiri sejak 15 Juni 2012 dan berada di bawah Marketing Directorate. UUS sejak didirikan memiliki performa yang sangat baik terbukti dari jumlah yang dimiliki dan total unit yang terjual selama tiga tahun terakhir. Pertumbuhan penjualan pembiayaan unit usaha syariah Adira Finance tahun2012-2015 tersaji pada Tabel 1.

Pertumbuhan yang positif terhadap penjualan pembiayaan syariah Adira Finance diikuti oleh pertumbuhan total aset di tahun 2015 sebesar $18.7 \%$ menjadi $33.7 \%$ dari total aset bisnis ditahun 2016 (ADMF, 2017). Melihat potensi yang dimiliki untuk dilakukannya spin off dan mengacu kepada Roadmap IKNB Syariah dan POJK No. 28/POJK.05/2014, Adira Finance perlu mengevaluasi kelayakan investasi dan sensitivitas unit usaha syariah jika dilakukan spin off. 
Atas dasar penjabaran di atas, maka tujuan dari penelitian ini adalah untuk menganalisis kelayakan investasi dan sensitivitas unit usaha syariah Adira Finance jika dilakukan spin off.

Tabel 1 Pertumbuhan penjualan pembiayaan unit usaha syariah Adira Finance tahun 20122015

\begin{tabular}{lcccc}
\hline \multicolumn{5}{c}{ Penjualan Pembiayaan Unit Usaha Syariah } \\
\hline Tahun & 2012 & 2013 & 2014 & 2015 \\
\hline Jumlah (dalam juta Rp) & 6107897 & 672326 & 2378067 & 4523333 \\
Pertumbuhan (\%) & - & $-88.99 \%$ & $253.71 \%$ & $90.21 \%$ \\
& & & & \\
Unit & 411885 & 48699 & 163236 & 254482 \\
Pertumbuhan (\%) & - & $-88.18 \%$ & $235.19 \%$ & $55.90 \%$ \\
\hline
\end{tabular}

Sumber: ADMF (2017)

\section{TINJAUAN PUSTAKA}

Salah satu permasalahan yang sering timbul bagi para pelaku usaha pada saat akan merencanakan mendirikan suatu usaha produksi adalah menganalisa kelayakan secara finansial usaha tersebut. Penelitian dan perhitungan biaya produksi, biaya peralatan, analisis untung ruginya, berapa besar modal dan keuntungan, serta tempo waktu pengembalian modal.

Jenis usaha yang didirikan akan berpengaruh pada analisa kelayakan finansial. Berbeda jenis usaha maka akan berbeda dalam perhitungan analisis kelayakan finansial, terutama pada usaha yang masih bersifat baru. Tujuan analisis kelayakan finansial adalah untuk mengetahui usaha layak dijalankan atau tidak. Analisis tersebut merupakan bagian dari perencanaan usaha. Dalam perencanaan usaha maka pengumpulan data yang sesuai dengan kondisi terkini merupakan kebutuhan mutlak dalam kelayakan finansial. Kesalahan dalam penentuan asumsi teknologi produksi, ketersediaan bahan baku dan fluktuasi harganya, sensitivitas biaya operasional, perkiraan tenaga kerja dapat menyebabkan ketidaktepatan analisis sehingga apabila rencana tersebut direalisasikan berpotensi merugi (Kusuma \& Mayasti, 2014).

Analisis sensitivitas memberikan gambaran sejauh mana suatu keputusan akan cukup kuat berhadapan dengan perubahan faktor-faktor atau parameter-parameter yang mempengaruhi. Analisis ini dilakukan dengan mengubah nilai dari suatu parameter pada suatu saat untuk selanjutnya dilihat pengaruhnya terhadap akseptabilitas suatu alternatif investasi. Parameterparameter yang biasanya berubah dan perubahannya bisa mempengaruhi keputusan-keputusan dalam studi ekonomi teknik adalah ongkos investasi, aliran kas, nilai sisa, tingkat bunga, tingkat pajak, dan sebagainya (Sufa, 2007).

Penelitian yang dilakukan oleh Dewi et al. (2014) dengan judul "Analisa sensitivitas dalam optimalisasi keuntungan produksi busana dengan metode simpleks". Hasil penelitian menunjukkan keuntungan optimal sebesar Rp1 893184 diperoleh dari 34 potong baju payung, 60 potong celana Aladdin ukuran XL, 68 potong celana Aladdin ukuran XXL, 96 potong celana Aladdin ukuran 3/4, 26 potong baju kerut dan 26 potong daster haji.

Penelitian yang dilakukan oleh Mulyani et al. (2016) dengan judul "Analisis kelayakan finansial usaha Agroindustri tahu (studi kasus Agroindustri Tahu Bapak Warijan di Desa Rambah Muda kecamatan Rambah Ilir Kabupaten Rokan Ulu). Penelitian ini menggunakan kriteria investasi, yakni NPV, Net B/C, IRR, dan Payback Period, serta untuk analisis sensitivitas menggunakan perubahan pada harga bahan baku kacang kedelai dan penurunan produksi. Hasil dari penelitian menunjukkan kriteria investasi selama 10 tahun Tahu Agroindustri layak dilakukan 
pengembangan. Hal tersebut dapat dilihat dari nilai NPV, yakni sebesar Rp420 095 475, Net B/C lebih besar dari 1 yakni 4, IRR lebih besar dari faktor diskon 12\% yakni 55\%, dan payback period selama 4 tahu 4 bulan. Hasil analisis sensitivitas kenaikan harga bahan baku kedelai $10 \%$ dan penurunan produksi sebesar $10 \%$ menunjukkan usaha ini tidak layak dilakukan karena nilai NPV negatif, Net B/C adalah 0, IRR lebih kecil dari faktor diskon 12\%, dan tidak ada payback periode. Berdasarkan hasil analisis sensitivitas kenaikan harga bahan baku kedelai dan penurunan produksi sangat mempengaruhi kelanjutan usaha Agroindustri Tahu BapakWarijan.

Mahyudi dan Husinsyah (2017) dalam penelitiannya yang berjudul "Analisis sensitivitas 5\% kelayakan usaha tani pembibitan karet Payung Satu (Hevea brasilliensis) di Desa Bentok Darat kecamatan Bati-Bati kabupaten Tanah Laut provinsi Kalimantan Selatan". Penelitian ini menggunakan kriteria investasi NPV, IRR, dan Net B/C dengan menggunakan sensitivitas 5\% dari perubahan faktor produksi. Hasil penelitian menunjukkan kelayakan usaha dengan NPV positif Rp226 328 495,34, Net B/C 1.528, dan IRR 29.48\%.

\section{METODE}

Penelitian dilakukan di Divisi Pembiayaan Syariah Adira Finace pada bulan Maret - Mei 2017. Data yang digunakan merupakan data penjualan unit usaha syariah tahun 2012 - 2016 Adira Finance dan laporan keuangan pembiayaan syariah Adira Finance tahun 2013 - 2016.

Dalam analisis investasi UUS Adira Finance menuju spin off akan menggunakan parameter dalam investasi, yakni NPV (Net Present Value), IRR (Interest Rate Return), B/C Ratio, dan BEP (Break Event Point/titik impas balik).

Net Present Value (NPV) adalah metode untuk menghitung selisih antara nilai sekarang investasi dengan nilai sekarang penerimaan-penerimaan kas bersih (operasional maupun terminal cash flow) di masa yang akan datang (Husnan \& Suwarsono, 1997). Menurut Gray et al. (1993) dalam Purwoko dan Arkeman (2004), formula yang digunakan untuk menghitung NPV adalah:

$$
N P V=\sum_{\tau=0}^{n} \frac{B_{\tau}-C_{\tau}}{(1+i)^{\dagger}}
$$

dimana:

Bt $=$ Benefit sosial bruto pada tahun $\mathrm{t}$

$\mathrm{Ct} \quad=$ Biaya sosial bruto sehubungan dengan proyek pada tahun $\mathrm{t}$

$\mathrm{i} \quad=$ Tingkat suku bungan pada periode $\mathrm{i}$

$\mathrm{t} \quad=$ Periode investasi $(\mathrm{t}=0,1,2,3, \ldots . \mathrm{n})$

Jika NPV bernilai positif atau > 0 maka proyek layak untuk dijalankan, jika NPV bernilai negatif atau $<0$ maka proyek tidak layak untuk dijalankan, jika NPV $=0$ maka proyek berada dalam keadaan break even point (BEP)

Internal Rate of Return (IRR) merupakan metode untuk menghitung tingkat bunga yang dapat menyamakan antara present value dari semua aliran kas masuk dengan aliran kas keluar dari suatu investasi proyek (Sulisyanto, 2010). Rumus adalah sebagai berikut:

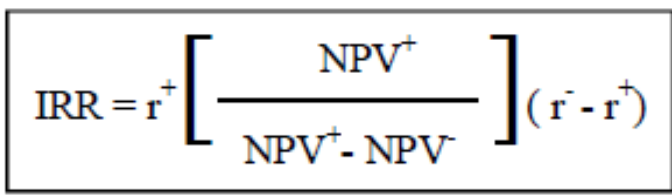


dimana:

$\mathrm{r}^{+} \quad=$ Discount rate yang menghasilkan NPV positif

$\mathrm{r}^{-} \quad=$ Discount rate yang menghasilkan NPV negatif

$\mathrm{NPV}^{+}=\mathrm{NPV}$ yang bernilai positif

$\mathrm{NPV}^{-}=\mathrm{NPV}$ yang bernilai negatif

Net Benefit Cost Ratio (Net B/C ) merupakan nilai perbandingan antara NPV yang bernilai positif dengan NPV yang bernilai negatif. Adapun rumus dari Net B/C rasio menurut Gray et al. (1993) dalam Purwoko dan Arkeman (2004) adalah:

$$
\text { Net } B / C=\frac{\sum_{t=1}^{n} \frac{B_{t}-C_{t}}{(1+i)^{t}} \text {, untuk } B_{t}-C_{t}>0}{\sum_{t=1}^{n} \frac{B_{t}-C_{t}}{(1+i)^{t}} \text {, untuk } B_{t}-C_{t}<0}
$$

dimana:

$\mathrm{Bt} \quad=$ Pendapatan proyek pada tahun tertentu

$\mathrm{Ct} \quad=$ Biaya proyek pada tahun tertentu

$\mathrm{n}=$ Umur proyek

$\mathrm{i} \quad=$ Tingkat bunga

$\mathrm{t} \quad=$ Tahun

Jika Net $\mathrm{B} / \mathrm{C}>1$ artinya proyek layak dijalankan secara finansial, Net $\mathrm{B} / \mathrm{C}=1$ artinya proyek sedang berada pada posisi break even point (BEP), dan jika Net B/C $<1$ artinya proyek tidak layak dijalankan secara finansial.

Metode Break Even Point atau titik impas adalah suatu kondisi dimana suatu usaha tidak untung maupun rugi. BEP menggambarkan kondisi penjualan yang harus dicapai melalui titik impas. Dikatakan mencapai titik impas jika jumlah hasil penjualan produknya pada suatu periode tertentu sama dengan jumlah biaya yang ditanggung, sehingga tidak menderita kerugian dan tidak memperoleh laba (Panjaitan et al., 2012). BEP pada dasarnya merupakan metode yang digunakan untuk analisa keuntungan. Rumus yang digunakan untuk perhitungan BEP adalah sebagai berikut:

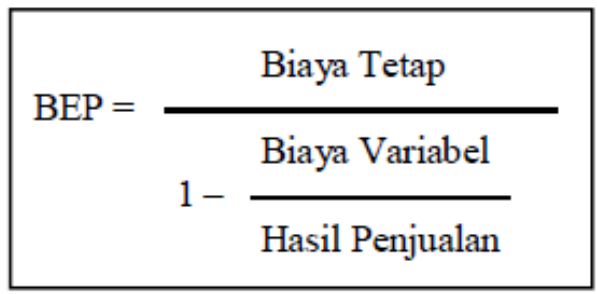

Analisa kelayakan UUS Adira Finance menuju spin off akan dilakukan pada produk pembiayaan kendaraan bermotor roda dua dan roda empat dengan menggunakan beberapa asumsi. Kriteria asumsi yang digunakan dalam analisis investasi UUS Adira Finance menuju spin off dapat dilihat pada Tabel 2.

Selain itu asumsi yang digunakan adalah faktor diskonto yang digunakan, dalam asumsi ini didasarkan pada suku bunga investasi Bank Danamon Syariah yakni 10\%. Keberlangsungan industri multifinance juga didukung dengan skema joint financing untuk pendanaan pembiayaan, dalam analisis investasi ini juga akan dilakukan dengan skema joint financing dengan komposisi pendanaan 90:10, yakni 90\% pendanaan oleh Bank Danamon Syariah dan 10\% pendanaan oleh UUS Adira Finance. 
Analisis sensitivitas yang digunakan dalam penelitian ini dilakukan dengan melihat sensitivitasnya terhadap penurunan jumlah unit yang dibiayai atau peningkatan komposisi pendanaan, skenario asumsi yang digunakan adalah unit yang dibiayai menurun 10\%, 20\% dan 30\% serta peningkatan komposisi pendanaan pembiayaan menjadi 80:20, 70:30, 60:40.

Tabel 2 Kriteria asumsi analisis investasi UUS Adira Finance menuju spin off

\begin{tabular}{lll}
\hline \multicolumn{1}{c}{ Kriteria } & Motor & Mobil \\
\hline Biaya Investasi & & \\
- Sewa gedung & $3 \mathrm{M}$ & $5 \mathrm{M}$ \\
- Peralatan kantor & $10 \mathrm{M}$ & $10 \mathrm{M}$ \\
\hline $\begin{array}{l}\text { Biaya Produksi } \\
\text { Biaya Tetap }\end{array}$ & \\
- Pendanaan pembiayaan & $18 \mathrm{~T}$ & $20 \mathrm{~T}$ \\
- Imbal jasa marketing channel & $3.36 \mathrm{M}$ & $25 \mathrm{M}$ \\
\hline $\begin{array}{l}\text { Biaya Variabel } \\
\text { - Biaya pelatihan SDM, bonus, insentif }\end{array}$ & $100 \mathrm{M}$ & $100 \mathrm{M}$ \\
- Insentif dealer & $60 \mathrm{M}$ & $100 \mathrm{M}$ \\
- Pajak & $1 \mathrm{~T}$ & $1 \mathrm{~T}$ \\
\hline Tingkat pengembalian investasi & 3 tahun & 5 tahun \\
\hline
\end{tabular}

\section{HASIL DAN PEMBAHASAN}

\section{Analisis Investasi}

Analisis kriteria investasi merupakan analisis yang digunakan untuk melihat layak atau tidaknya usaha untuk dijalankan. Analisis kriteria investasi disesuaikan dengan masa tenor pembiayaan yaitu tiga tahun untuk kendaraan bermotor roda dua dan lima tahun untuk kendaraan bermotor roda empat. Analisis kriteria investasi ini menggunakan indikator kelayakan yaitu diantaranya Net Present Value (NPV), Net Benefit Cost Ratio (net B/C), Interest Rate Return (IRR) dan Break Event Point (BEP). Hasil perhitungan kriteria investasi pada pembiayaan kendaraan bermotor UUS Adira Finance dapat dilihat pada Tabel 3.

Tabel 3 Hasil analisis investasi UUS Adira Finance

\begin{tabular}{llll}
\hline Parameter & Motor & Mobil & Keterangan \\
\hline NPV & $11,75(-)$ & $2,81(-)$ & Tidak Layak \\
B/C ratio & - & - & \\
IRR & - & - & \\
BEP & - & - & \\
\hline
\end{tabular}

Dari hasil analisis investasi pada Tabel 3 dapat dilihat nilai NPV lebih kecil dari pada 0 (nol) atau bernilai negatif. Menurut Umar (2007) jika NPV < 0, maka usulan proyek ditolak, berdasarkan hasil analisa investasi UUS Adira Finance maka usulan untuk dilakukan nya spin off dengan pendanaan penuh dikatakan tidak layak. Dikarenakan hasil NPV $<0$ atau bernilai negatif maka analisis tidak dilanjutkan untuk parameter lain.

Skema joint financing menjadi solusi bagi industri pembiayaan untuk keberlangsungan usaha, hal ini dikarenakan industri pembiayaan adalah lembaga keuangan yang tidak dapat mengumpulkan 
dana langsung dari masyarakat sehingga melakukan joint financing dengan pihak bank menjadi pilihan untuk menekan resiko pembiayaan. Besarnya komposisi joint financing tergantung dari kesepakatan, namun untuk penelitian ini akan menggunakan komposisi joint financing 90:10 yakni 90\% berasal dari Bank Danamon Syariah dan 10\% berasal dari UUS Adira Finance. Hasil analisa investasi UUS Adira Finance dengan skema joint financing dapat dilihat pada Tabel 4.

Dari tabel 4 dapat dilihat, UUS Adira Finance dapat dilakukan spin off jika pendanaan unit yang akan dibiayai dilakukan dengan skema joint financing. Dengan skema joint financing total biaya yang akan ditanggung oleh UUS Adira Finance tidak terlalu besar sehingga usaha dapat terus berjalan.

Tabel 4 Hasil analisis investasi UUS Adira Finance skema joint financing 90:10

\begin{tabular}{llll}
\hline Parameter & Motor & Mobil & Keterangan \\
\hline NPV & $0.41(+)$ & $8.36(+)$ & Layak \\
B/C ratio & $1.3(+)$ & $1.54(+)$ & Layak \\
IRR & $12 \%$ & $19.3 \%$ & Layak \\
BEP & 2 tahun 5 bulan & 1 tahun & Layak \\
\hline
\end{tabular}

\section{Analisis Sensitivitas}

Analisis sensitivitas dilakukan dalam dua skenario, yakni 1) jika unit yang terjual turun $10 \%, 20 \%$, dan 30\%, 2) jika komposisi joint financing adalah 80:20, 70:30 dan 60:40. Hasil analisis sensitivitas dari dua skenario tersebut dapat dilihat pada Tabel 5 dan Tabel 6 .

Tabel 5 Analisis sensitivitas UUS Adira Finance skenario penurunan jumlah unit yang dibiayai

\begin{tabular}{lllcccc}
\hline \multirow{2}{*}{ Parameter } & \multicolumn{2}{c}{$10 \%(-)$} & \multicolumn{2}{c}{$20 \%(-)$} & \multicolumn{2}{c}{$30 \%(-)$} \\
\cline { 2 - 7 } & \multicolumn{1}{c}{ Motor } & \multicolumn{1}{c}{ Mobil } & Motor & Mobil & Motor & Mobil \\
\hline NPV & $0.15(+)$ & $7.32(+)$ & $0.12(-)$ & $6.31(+)$ & $0.38(-)$ & $5.26(+)$ \\
IRR & $37.5 \%(+)$ & $28.3 \%(+)$ & - & $28.3 \%(+)$ & - & $28.3 \%(+)$ \\
B/C Ratio & $1.36(+)$ & $1.54(+)$ & - & $1.54(+)$ & - & $1.54(+)$ \\
\multirow{2}{*}{ PP } & 2 tahun 8 & 1 tahun 1 & & 1 tahun 2 & & 1 tahun 4 \\
& bulan & bulan & - & bulan & - & bulan \\
\hline
\end{tabular}

Tabel 6 Analisis sensitivitas UUS Adira Finance skenario komposisi joint financing

\begin{tabular}{lcccccc}
\hline \multirow{2}{*}{ Parameter } & \multicolumn{2}{c}{$80: 20$} & \multicolumn{2}{c}{$70: 30$} & \multicolumn{1}{c}{$60: 40$} \\
\cline { 2 - 7 } & Motor & \multicolumn{1}{c}{ Mobil } & Motor & \multicolumn{1}{c}{ Mobil } & Motor & \multicolumn{1}{c}{ Mobil } \\
\hline NPV & $0.93(-)$ & $8.37(+)$ & $1.42(-)$ & $5.88(+)$ & $3,64(-)$ & $4.64(+)$ \\
IRR & - & $28.3 \%(+)$ & - & $29 \%(+)$ & - & $28.6 \%(+)$ \\
B/C Ratio & - & $1.55(+)$ & - & 1.55 & - & 1.55 \\
PP & - & 1 tahun & - & 2 tahun 1 bulan & - & 2 tahun 7 bulan \\
\hline
\end{tabular}

Dari hasil analisis sensitivitas pada beberapa skenario dapat dilihat produk motor lebih rentan terhadap perubahan skenario, hal ini disebabkan biaya investasi yang dibebankan kepada motor tidak sebanding dengan harga per unit kendaraan yang dibiayai. Efisiensi biaya operasional pada produk pembiayaan motor perlu dilakukan mengingat margin yang diperoleh cukup kecil. Salah satu strategi yang dapat dilakukan oleh UUS Adira Finance terhadap produk motor adalah melakukan pemasaran langsung (direct marketing) kepada konsumen. 
Pemasaran langsung merupakan suatu bentuk hubungan langsung dengan konsumen yang ditargetkan, Konsumen dapat segera memberikan respon sehingga dapat menimbulkan hubungan pelanggan yang loyal. Dalam pemasaran langsung perusahaan dapat berkomunikasi langsung dengan pelanggan dalam mempelajari kebutuhannya. Pemasaran langsung telah berkembang pesat dalam pemasaran business to business (B2B) sebagai tanggapan terhadap meningkatnya biaya pemasaran akibat tenaga penjualan (Kotler \& Amstrong, 2012). Dengan melakukan pemasaran langsung kepada konsumen mampu mereduksi biaya insentif kepada marketing channel yang disinyalir mampu menggerus besarnya margin yang diperoleh.

Selain itu penggabungan kantor operasional motor dengan mobil juga dapat membantu pengurangan biaya investasi pada kendaraan motor, sehingga biaya yang dikeluarkan pada motor hanya untuk pendanaan unit yang akan dibiayai.

\section{SIMPULAN}

Dari hasil analisis investasi UUS Adira Finance dinyatakan tidak layak jika dilakukan spin off dengan skema pendanaan sepenuhnya dibebankan kepada UUS Adira Finance karena NPV yang diperoleh negatif atau <0 yakni -11.75 untuk pembiayaan motor dan -2.81 untuk pembiayaan mobil. Dengan hasil NPV negatif maka analisa tidak dilanjutkan untuk parameter lain. Skema joint financing menjadi solusi bagi UUS Adira Finance jika akan dilakukan spin off. Hasil analisis investasi dengan skema join financing diperoleh NPV yang positif yakni 0.41 untuk pembiayaan motor dan 8.36 untuk pembiayaan mobil. B/C ratio lebih besar dari 1 yakni 1.3 untuk pembiayaan motor dan 1.54 untuk pembiayaan mobil. IRR yang diperoleh lebih besar dari faktor diskon (10\%) yakni $12 \%$ untuk pembiayaan motor dan 19.3\% untuk pembiayaan mobil. BEP diperoleh 2 tahun 5 bulan untuk pembiayaan motor dan 1 tahun untuk pembiayan mobil.

Dari hasil analisis sensitivitas pada beberapa skenario, produk pembiayaan motor lebih rentan terhadap perubahan skenario dibandingkan pembiayaan mobil, hal ini disebabkan biaya yang dibebankan kepada motor tidak sebanding dengan harga per unit kendaraan yang dibiayai. Efisiensi biaya operasional pada produk pembiayaan motor perlu dilakukan mengingat margin yang diperoleh cukup kecil. Salah satu strategi yang dapat dilakukan oleh UUS Adira Finance terhadap produk motor adalah melakukan pemasaran langsung (direct marketing) kepada konsumen. Dengan melakukan pemasaran langsung kepada konsumen mampu mereduksi biaya insentif kepada marketing channel yang disinyalir mampu menggerus besarnya margin yang diperoleh.

\section{DAFTAR PUSTAKA}

Dewi, A.A.S.D.S., Tastrawati, N.K.T., Sari, K. (2014) Analisis sensitivitas dalam optimalisasi keuntungan produksi busana dengan metode simpleks, Jurnal Matematika, 4(2), 90-101.

Gittinger, J.P. (1986) Economic Analysis of Agricultural Projects. Ed ke-2. Completely Revised and Expanded. Baltimore, John Hopkins University Press.

Hamid, A. (2015) The Impact of spin-off policy to the probability on Indonesian Islamic banking industry. Al-Iqtishad, 8(1), 117-126.

Husnan, S., Suwarsono. (1997) Studi Kelayakan Proyek. Cetakan ke- 2, Yogyakarta, UPP AMP YKPN.

Kotler, P., Amstrong, G. (2012) Principles of Marketing: $14^{\text {th }}$ ed, New Jersey, Pearson Prentice Hall.

Kusuma, P.T.W.W. \& Mayasti, N.K.I. (2014) Analisa kelayakan finasial pengembangan usaha produksi komoditas lokal: mie berbasis jagung, Jurnal AGRITECH universitas Gadjah Mada, 34(2), 194-202 
Mahyudi, F., Husinsyah. (2017). Analisis sensitivitas 5\% kelayakan usaha tani pembibitan karet "Payung Satu" (Hevea brasilliensis) di Desa Bentok Darat Kecamatan Bati-Bati Kabupaten Tanah Laut Provinsi Kalimantan Selatan, Jurnal Zira`ah, 42(3), 208-214.

Mulyani, U., Yusmini, Edwina, S. (2016) Analisis kelayakan finansial usaha Agroindustri Tahu (Studi kasus Agroindustri Tahu Bapak Warijan di Desa Rambah Muda Kecamatan Rambah Hilir Kabupaten Rokan Hulu), Jom Faperta, 3(1).

Panjaitan, J.L.U., Limbong, W.H., \& Suryani, A. (2012) Strategi pengembangan usaha agroindustri tepung gandum di Gapoktan gandum, Kabupaten Bandung. Jurnal Manajemen Pengembangan Industri Kecil Menengah, 7(1), 85-93.

Purwoko, Arkeman ,Y. (2004) Kelayakan industri kerupuk jamur tiram di Kabupaten Bogor, Jurnal Teknik Industri Pertanian, 13(3), 83-91.

Sufa, M.F. (2007) Analisis sensitivitas pada keputusan pembangunan meeting hall untuk minimasi resiko investasi. Jurnal Ilmiah Teknik Industri, 5(3), 97-105.

Suliyanto. (2010) Studi Kelayakan Bisnis: Pendekatan Praktis. Oktaviani HS, editor, Yogyakarta, CV. Andi Offset.

Umar, H. (2000) Studi Kelayakan Bisnis, Manajemen, Metode, dan Kasus, Jakarta, PT. Gramedia Pustaka Utama. 